\title{
Heat shock modulates adipokines expression in 3T3-L1 adipocytes
}

\author{
Umberto Bernabucci, Loredana Basiricò, Patrizia Morera, Nicola Lacetera, Bruno Ronchi \\ and Alessandro Nardone
}

Dipartimento di Produzioni Animali, Università della Tuscia, Viterbo 01100, Italy

(Correspondence should be addressed to U Bernabucci; Email: bernab@unitus.it)

\begin{abstract}
Studies have demonstrated that heat shock is associated with alteration in energy metabolism. In this study, we investigated the effect of heat shock on gene expression and secretion of adiponectin and leptin, and gene expression of Hspa2 and Ppary in 3T3-L1 adipocytes. Compared with $37^{\circ} \mathrm{C}$, adiponectin mRNA was higher at $39^{\circ} \mathrm{C}$, and lower at $41^{\circ} \mathrm{C}$. Leptin mRNA was higher when adipocytes were exposed to $41^{\circ} \mathrm{C}$ compared with 37 and $39^{\circ} \mathrm{C}$. Secretion of adiponectin increased at $39^{\circ} \mathrm{C}$, and when cells were exposed to $41^{\circ} \mathrm{C}$ it was not detectable. Leptin secretion increased significantly at $41^{\circ} \mathrm{C}$, compared with 37 and $39^{\circ} \mathrm{C}$. Hspa2 mRNA was increased at $39^{\circ} \mathrm{C}$, and the highest level was reached at $41^{\circ} \mathrm{C}$. Ppary mRNA exhibited a substantial increase in a temperature-dependent manner. The study provides the first evidence of a possible direct effect of heat shock on adiponectin and leptin gene expression and secretion, and demonstrates that the expression of the two adipokines is differentially regulated at the temperatures tested.
\end{abstract}

Journal of Molecular Endocrinology (2009) 42, 139-147

\section{Introduction}

Future climate scenarios suggest that higher global mean temperatures could result in marked changes in the frequency of heat waves (Kattenberg et al. 1996). In farm animals, the alteration of energy metabolism and immune response that may lead to the increase of morbidity and mortality during heat waves are well documented (Lacetera et al. 2005, 2006). In dairy, cattle alterations in the endocrine status under hot environment have been reported (Beede \& Collier 1986, Bertoni 1998, Ronchi et al. 2001). Ronchi et al. (1999) reported a direct effect of heat stress on energy and lipid metabolism and liver enzymatic activities. In our studies carried out on periparturient dairy cows, we observed alteration of lipid metabolism, oxidative status, and increases of circulating adipocytokine such as leptin in animals exposed to hot environment (Bernabucci et al. 2002, 2006). Even though several pieces of information are available on the effects of hot conditions on metabolism, no cellular mechanisms responsible for metabolic modifications are clarified yet. In humans, elderly persons, children, and persons with certain medical chronic conditions (such as circulatory problems, diabetes, a previous stroke, overweight, and a weak or damaged heart) are at the greatest risk for heat-related illness and death (McGeehin \& Mirabelli 2001, Braga et al. 2002,
Naughton et al. 2002). Meanwhile although heat-related physiological changes observed under these chronic diseases are well documented (Semenza et al. 1999, Morabito et al. 2005), the cellular mechanisms involved in the increase of heat-related risk morbidity and mortality among at risk human populations have not been clearly elucidated yet.

In the past decade, several researchers demonstrated that adipose tissue is an active participant in regulating physiologic and pathologic processes, including carbohydrate/lipid metabolism, inflammation, cardiovascular diseases (CVD), diabetes, and obesity. Adipose tissue carries out its regulatory function by secreting biologically active molecules called adipocytokines (Trayhurn 2005). Among these, adiponectin and leptin are expressed almost exclusively in differentiated adipocytes, and are crucial in the regulation of energy balance and carbohydrate/lipid metabolism in humans and animals (Havel 2002, 2004). Adiponectin is one of the most important and abundant adipocytokines and exerts profound anti-diabetic, anti-atherogenic, and anti-inflammatory roles (Goldstein \& Scalia 2004, Pittas et al. 2004). Conversely, leptin is related to body fat and is a modulator of the appetite and the energetic balance and may act as an endocrine, a paracrine, as well as an autocrine factor (Friedman 2002, Hall et al. 2002). Animal and human data demonstrate that hypoadiponectinemia and hyperleptinemia associated with a 
deregulation of genes expression of these adipokines play a central role in the genesis of the CVD, obesity, and diabetes risk factor (Arita et al. 1999, Hotta et al. 2000, Margetic et al. 2002, Rothenbacher et al. 2005, Klein et al. 2006).

It is clear that adipose tissue plays a critical role in the regulation of lipid and carbohydrate metabolism and in the pathogenesis of the metabolic syndrome, and that hot conditions are responsible for the alteration of carbohydrate/lipid metabolism. Therefore, the aim of the present study was to investigate if and how adipose tissue is involved in the metabolic modification observed under hot environment. For that, we investigated in vitro the effect of heat shock on gene expression and secretion of adiponectin and leptin in 3T3-L1 adipocytes. Expression of Hspa2 as biomarker of cellular heat shock, and Ppar $\gamma$ as a regulator of those adipokines were also investigated.

\section{Materials and methods}

\section{Materials}

DMEM, penicillin, streptomycin, D-biotin, insulin, 3-isobutyl-1-methylxanthine (IBMX), dexamethasone, BSA, and all cell culture reagents were obtained from Sigma unless otherwise mentioned. Fetal bovine serum (FBS) was purchased from Gibco and the same lot of FBS was used throughout the study.

\section{Cell culture and differentiation}

Murine 3T3-L1 preadipocytes were obtained from European collection of cell culture (Sigma-Aldrich). Cells were cultured at $37^{\circ} \mathrm{C}$ in a humidified atmosphere of $5 \% \mathrm{CO}_{2}$. The cells were maintained in growth medium with the following constituents: DMEM supplemented with $25 \mathrm{mM}$ HEPES, $8 \mathrm{mg} / 1$ D-biotin, $100 \mathrm{U} / \mathrm{ml}$ penicillin, and $100 \mu \mathrm{g} / \mathrm{ml}$ streptomycin and $10 \%$ FBS. Cells were seeded in six-well plates and after 2 days postconfluence, differentiation was induced by exposing the cells to medium A supplemented with $10 \% \mathrm{FBS}, 0 \cdot 5 \mathrm{mM}$ IBMX, $1 \mu \mathrm{M}$ dexamethasone, and $10 \mu \mathrm{g} / \mathrm{ml}$ insulin for 3 days. Then, cells were incubated with growth medium containing $10 \%$ FBS and $5 \mu \mathrm{g} / \mathrm{ml}$ insulin. After 3 days, the medium was replaced with growth medium containing 10\% FBS and changed regularly. Between 8 and 12 days after the induction, we verified that more than $90 \%$ of the cells showed fat accumulation by using an inverted microscope (Hund Wetzlar, Germany). The cells were placed in serum-free medium using DMEM and supplemented with $0 \cdot 5 \%$ BSA, $25 \mathrm{mM}$ HEPES, $8 \mathrm{mg} / \mathrm{l}$ D-biotin, $100 \mathrm{U} / \mathrm{ml}$ penicillin, and $100 \mu \mathrm{g} / \mathrm{ml}$ streptomycin for $12 \mathrm{~h}$ before treatments.

\section{Treatments}

The 3T3-L1 adipocytes were incubated at different temperatures: $37^{\circ} \mathrm{C}$ (control temperature), 39, and $41^{\circ} \mathrm{C}$. For each temperature, the samples were collected after $0,2,4,8,16$, and $24 \mathrm{~h}$ of exposure to study the kinetic of cellular response to heat shock. Some culture plates of adipocytes were exposed at $41{ }^{\circ} \mathrm{C}$ for $2 \mathrm{~h}$, and then at $37^{\circ} \mathrm{C}$ for $24 \mathrm{~h}$. The samples were collected immediately before initiating and ending of thermal stress and 2, 4, 8, 16, and $24 \mathrm{~h}$ after recovering at $37^{\circ} \mathrm{C}$.

For heat shock and control treatments, culture plates were maintained in a humidified incubator with 5\% $\mathrm{CO}_{2}$. Temperature treatments were adopted to mime mild or severe hyperthermia typical of hot season. All incubations were performed in quadruplicate (four wells).

\section{RNA extraction and cDNA synthesis}

Total RNA was isolated from 3T3-L1 adipocytes using Qiazol Lysis reagent (Qiagen) according to the manufacture's instructions. RNA was quantified using a spectrophotometer set at $260 \mathrm{~nm}$, and all the samples had a $260 / 280 \mathrm{~nm}$ absorbance ratio of $1 \cdot 7-1 \cdot 9$. The integrity of the RNA was checked by visualization of 18 and $28 \mathrm{~s}$ ribosomal bands on an agarose gel. One microgram of total RNA was reverse transcribed with ImProm-II reverse transcription system (Promega), in a total volume of $20 \mu \mathrm{l}$ on a PCR Express thermal cycler (Hybaid, Ashford, UK). Controls without reverse transcription were performed to exclude the possibility of DNA contamination.

\section{Real-time PCR}

Real-time PCR was done for four target genes (leptin, adiponectin, Hspa2, and Ppary) and two housekeeping genes (18s rRNA, $\beta$-actin). Real-time PCR was performed in the LyghtCycler (Roche Applied Science) using QuantiTect SYBR Green PCR Master Mix (Qiagen). Oligonucleotide primers for adiponectin and leptin were designed with Polyprimers software (Valentini 2006) and synthesized by MWG-Biotech (Ebersberg, Germany). For Ppar $\gamma$, Hspa2, $\beta$-actin and 18s rRNA QuantiTect primer assays from Qiagen were used. In Table 1 are shown the specific characteristics of primers used for the real-time PCR. PCR products were subjected to a melting curve analysis on the LyghtCycler and subsequently 2\% agarose/Trisborate-EDTA gel electrophoresis to confirm amplification specificity and amplicon size. To allow relative quantification after PCR, standard curves were constructed from the standard reactions for each target 
Table 1 Sequences of PCR primers, position in coding sequence (CDS), PCR product length, and GeneBank of the European Molecular Biology Laboratory (EMBL) accession number of the used published mouse nucleic acid sequences

$$
\text { Primer sequence }\left(5^{\prime} \rightarrow 3^{\prime}\right)
$$

CDS

Length

EMBL

Gene

Adiponectin

For $^{\mathrm{a}}$

Rev $^{\mathrm{b}}$

Leptin

For

Rev

Ppary

Hspa2

18s rRNA

$\beta$-actin

${ }^{\mathrm{a}}$ Forward.

${ }^{\mathrm{b}}$ Reverse.

and housekeeping genes by plotting crossing point (Cp) values, i.e., the cycle number at which the fluorescence signal exceeds background versus log cDNA dilution. The Cp readings for each of the unknown samples where then used to calculate the amount of either the target or housekeeping relative to the standard, using the second derivative maximum method with the LyghtCycler analysis software 3.5 (Roche Applied Science). Mouse 18s rRNA housekeeping gene was used to normalize all gene expressions, since it was the one that most remained unchanged during heat treatment.

\section{Measurement of adipokines by ELISA}

Adiponectin and leptin were measured in cell culture media using commercial ELISA kits. The assays were conducted in 96-well microplates according to the manufacture's instructions, with a SLT Spectra I microplate spectrophotometer (SLT Lab-instruments GesmbH, Grodig/Salzburg, Austria). Mouse Leptin Assay Kit (IBL, Gunma, Japan) was used for leptin (sensitivity: $0.86 \mathrm{pg} / \mathrm{ml}$ ) and mouse adiponectin ELISA Kit (Linco Research, St Charles, MO, USA) was used for adiponectin (sensitivity: $0.5 \mathrm{ng} / \mathrm{ml}$ ) determination. After collecting culture medium for adipokines determination, cells were washed twice with ice-cold PBS and lysed with Tris-buffered saline containing 1\% NP-40, $0.5 \%$ deoxycholic acid, $0 \cdot 1 \%$ SDS, $2 \mathrm{mM}$ EDTA, and $1 \mathrm{mM}$ phenylmethylsulfonyl fluoride. Each lysate sample was centrifuged at 15000 r.p.m for $15 \mathrm{~min}$ at $10^{\circ} \mathrm{C}$. After the upper lipid layer was removed, protein levels in the supernatant were measured by BCA protein assay kit from Pierce (Rockford, IL, USA) and adipokine concentrations were normalized per total extracted proteins. Adiponectin and leptin levels were expressed as $\mathrm{ng} / \mu \mathrm{g}$ and $\mathrm{pg} / \mu \mathrm{g}$ of total extracted proteins respectively.
Recombinant human adiponectin (MBL, Woburn, MA, USA; $5 \mathrm{ng} / \mathrm{ml}$ ) was added to cell media of six culture plates exposed to 37 and $41{ }^{\circ} \mathrm{C}$ respectively. After 2, 4, 8, 16, and $24 \mathrm{~h}$ incubation, human adiponectin ELISA kit (Linco Research) was used for adiponectin determination (sensitivity: $0.78 \mathrm{ng} / \mathrm{ml}$ ).

\section{Analysis of cell viability}

Cell viability was determined by XTT (sodium 3 '-(1(phenylaminocarbonyl)-3,4-tetrazolium)-bis (4-methoxy-6-nitro) benzene sulfonic acid hydrate) assay using cell proliferation kit II (XTT) from Roche Applied Science according to the manufacturer's instructions. Briefly, the cells were seeded into 96-well microplates at an optimal density, differentiated to adipocytes, serum starved, and exposed to treatments $\left(37,39\right.$, and $\left.41^{\circ} \mathrm{C}\right)$. For each temperature, the samples were collected after $0,2,4,8,16$, and 24 h of exposure in the same way as used for other analysis. The cell culture medium was changed to $100 \mu \mathrm{l}$ of medium A with $0.5 \% \mathrm{BSA}$, and then $50 \mu \mathrm{l}$ of XTT labeling mixture was added to each well. After 24 -h incubation at $37^{\circ} \mathrm{C}$, absorbance was measured using a microplate spectrophotometer at a wavelength of $450 \mathrm{~nm}$. Background absorbance was subtracted from each row value. The results were expressed as optical density.

\section{Statistical analysis}

Data for all variables measured were analyzed as repeated measures using the general linear model (GLM) procedure of SAS (1999). The model included fixed effects: temperature $\left(37,39\right.$, and $\left.41^{\circ} \mathrm{C}\right)$, time of exposure to different temperatures $(0,2,4,8,16$, and $24 \mathrm{~h}$ ), interaction temperature $\mathrm{X}$ time of exposure, and the error term. Least square means were separated with 
the predicted difference (PDIFF) procedure of SAS (1999). Data are reported as least-square means with standard errors. Significance was declared at $P<0 \cdot 05$.

\section{Results}

\section{Heat shock differently affects adipokines gene expression}

To examine the effect of heat shock on adipokines gene expression, 3T3-L1 adipocytes were incubated at different temperatures for $24 \mathrm{~h}$. Total RNA was extracted and mRNA levels of adiponectin and leptin were measured by real-time PCR. Kinetics of heat shock response in terms of the induction of mRNA adipokines and accumulation over time were observed.

The results showed that heat shock affected differently the two adipokines. Compared with control temperature $\left(37^{\circ} \mathrm{C}\right)$, adiponectin gene expression increased by $55 \%(P<0.05)$ at $39^{\circ} \mathrm{C}$ and decreased by $78 \%(P<0 \cdot 05)$ at $41{ }^{\circ} \mathrm{C}$ (Fig. 1A). The time-course study of adiponectin expression is shown in Fig. 1B. Control cells showed a decrease $(P<0.05)$ of adiponectin gene expression until 4-h exposure and then started to recover $(P>0 \cdot 05)$. Decrease $(P<0 \cdot 05)$ of adiponectin mRNA was also observed after 2-h exposure at 39 and most of all at $41^{\circ} \mathrm{C}$. Then, from 2- to 24-h exposure mRNA levels increased $\left(b=0 \cdot 066, R^{2}=0 \cdot 84, P<0 \cdot 05\right)$ in cells exposed to $39^{\circ} \mathrm{C}$, meanwhile at $41{ }^{\circ} \mathrm{C}$ adiponectin mRNA remained stable.
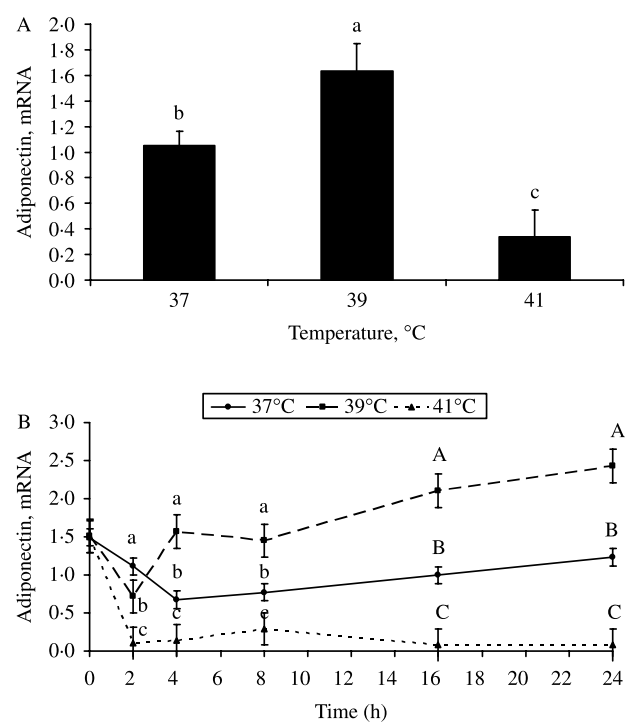

Figure 1 Temperature-dependent $(A)$ adiponectin and $(C)$ leptin mRNA, kinetic of heat shock response of (B) adiponectin and (D) leptin mRNA expressions in 3T3-L1 adipocytes. Each mRNA level was determined using quantitative real-time PCR as described under Materials and methods. Values are normalized to mouse $18 \mathrm{~s}$ rRNA expression. Results are LSmeans \pm S.E.M. of triplicate determinations. (A) and (C) report

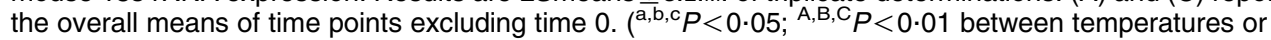
between temperatures within hours.)
A $16 \cdot 6$-fold increase $(P<0 \cdot 01)$ of leptin mRNA (Fig. 1C) was observed when adipocytes were exposed to $41^{\circ} \mathrm{C}$ compared with control temperature $\left(37^{\circ} \mathrm{C}\right)$. No significant difference was found between cells exposed to 37 and $39^{\circ} \mathrm{C}$ in leptin mRNA levels (Fig. 1C). Response to time exposure of leptin mRNA at different temperatures (Fig. 1D) showed an increase $(P<0 \cdot 05)$ in leptin mRNA level within 2-h exposure only in cells exposed to $41^{\circ} \mathrm{C}$. Then, after a stable period of $14 \mathrm{~h}$, mRNA was up-regulated maximally between 16 and $24 \mathrm{~h}$. At 37 and $39^{\circ} \mathrm{C}$, 3T3-L1 adipocytes did not exhibit any significant change during the 24-h exposure (Fig. 1D).

Kinetic of adiponectin and leptin mRNA after $2 \mathrm{~h}$ of heat shock is reported in Fig. 3A. Adiponectin mRNA had already decreased $(P<0.05)$ after 2-h period of heat shock at $41^{\circ} \mathrm{C}$; then started to recover already after $2 \mathrm{~h}$ of the recovery time. On the contrary, leptin mRNA increased $(P<0 \cdot 05)$ during the 2 -h heat shock and continued to increase $(P<0 \cdot 05)$ until $2 \mathrm{~h}$ after heat shock; then started to decrease reaching the basal levels $8 \mathrm{~h}$ after heat shock.

\section{Heat shock differently affects also adipokine secretion levels}

The secretion of adipokines in medium was examined next, using specific ELISAs. Secretion levels of adiponectin and leptin showed a trend that paralleled the changes of their mRNA levels. Particularly, secretion of
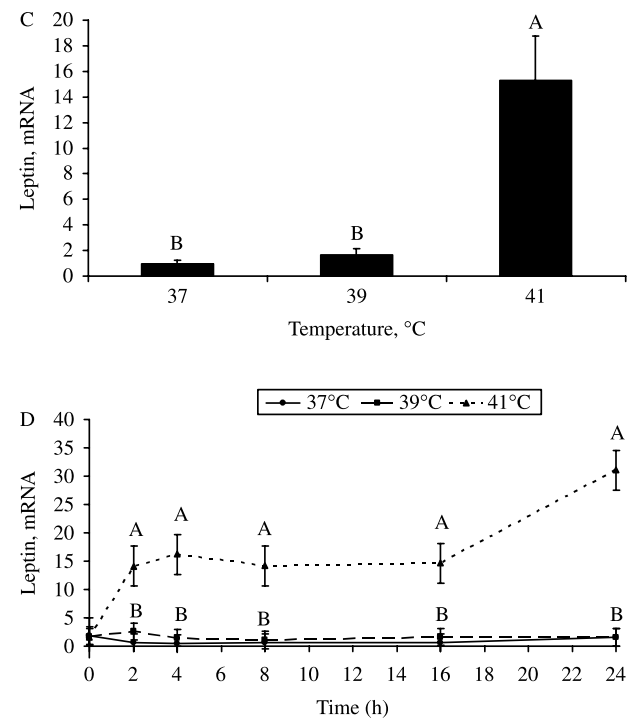

\section{(1)}

\author{
(n)
}


adiponectin in medium increased $(P<0 \cdot 01)$ at $39^{\circ} \mathrm{C}$, and at $41^{\circ} \mathrm{C}$ it was not detectable (Fig. 2A). Adiponectin secretion levels in control cells were quite stable until the end of heat shock exposure. In adipocytes exposed to $39^{\circ} \mathrm{C}$, adiponectin started to increase after 2-h exposure reaching the maximum at the end of the exposure time (Fig. 2B). When cells were exposed to $41{ }^{\circ} \mathrm{C}$, adiponectin was rapidly reduced showing not detectable levels already after 2-h exposure and remained undetectable until 24-h (Fig. 2B).

Unlike adiponectin, the highest $(P<0.05)$ concentration of leptin was found in cells exposed to $41^{\circ} \mathrm{C}$, when compared with 37 and $39{ }^{\circ} \mathrm{C}$ (Fig. 2C). The kinetic of leptin secretion (Fig. 2D) showed a gradual increase during $24 \mathrm{~h}$ in cells exposed to $41^{\circ} \mathrm{C}$, and remained quite stable in cells exposed to 37 and $39{ }^{\circ} \mathrm{C}$ (Fig. 2D).

A time-course study of adipokines secretion from 3T3-L1 adipocytes, after $2 \mathrm{~h}$ of heat shock at $41{ }^{\circ} \mathrm{C}$, was also performed (Fig. 3B). Significant decrease in adiponectin secretion levels was observed after 2-h period of heat shock at $41{ }^{\circ} \mathrm{C}$; whereas after $4 \mathrm{~h}$ of recovery time a significant increase of secretion levels was observed. Meanwhile, a significant increase in leptin secretion levels was seen after 2-h exposure to $41^{\circ} \mathrm{C}$ and remained stable until the end of the recovery time.

To verify if decreases of adiponectin secretion observed at $41{ }^{\circ} \mathrm{C}$ were not due to degradation in the cell media during the incubations time, recombinant human adiponectin $(5 \mathrm{ng} / \mathrm{ml})$ was added to cell media
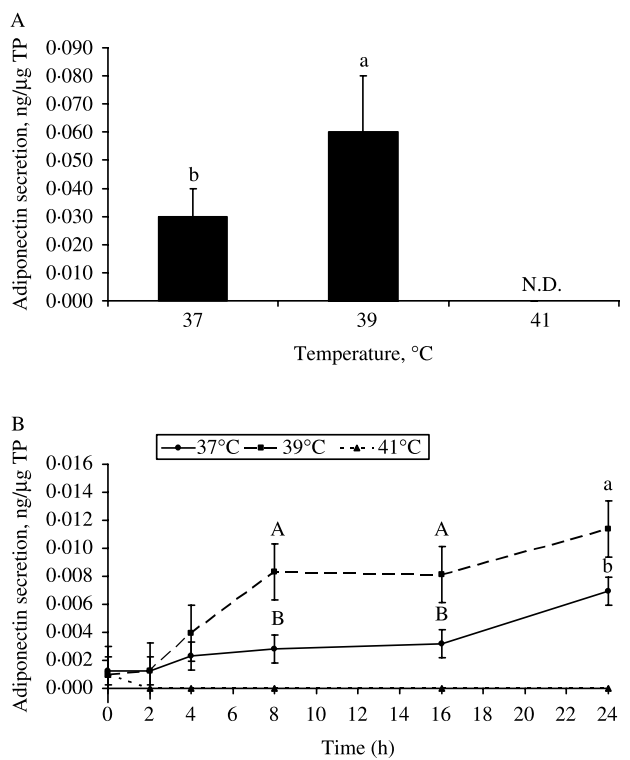

Figure 2 Temperature-dependent $(A)$ adiponectin and $(C)$ leptin secretion, kinetic of heat shock response of (B) adiponectin and (D) leptin secretion in 3T3-L1 adipocytes. Concentrations of adipokines were determined by ELISA and adjusted for total protein (TP) levels in the cell lysate. Results are LSmeans \pm S.E.M. of triplicate determinations. Adiponectin in cells exposed to $41^{\circ} \mathrm{C}$ resulted not-detectable (ND). $(\mathrm{A})$ and $(\mathrm{C})$ report the overall means of time points excluding time 0 . $\left({ }^{\mathrm{a}, \mathrm{b}, \mathrm{c}} P<0.05\right.$; ${ }^{\mathrm{A}, \mathrm{B}} P<0.01$ between temperatures or between temperature within hours.)

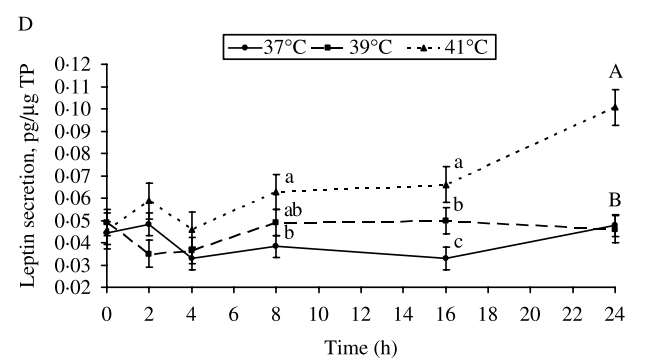

and recovery was measured during the incubation process at 37 and $41^{\circ} \mathrm{C}$. After 2, 4, 8, 16, and $24 \mathrm{~h}$ incubation, adiponectin recovery was $100 \cdot 8 \pm 0 \cdot 6 \%$ and $100 \cdot 0 \pm 1 \cdot 6 \%$ on average of the control sample (time 0 ) at 37 and $41{ }^{\circ} \mathrm{C}$ respectively.

\section{Gene expression of Hspa2 and Ppary after exposure to heat shock}

Quantitative changes of Hspa2 and Ppary gene expressions were analyzed in 3T3-L1 adipocytes by real-time PCR after exposure to different temperatures. We performed also a time course of Hspa2 and Ppary mRNA expression during 24-h exposure. As shown in Fig. 4A, Hspa2 gene expression was stimulated $(P<0.05)$ at $39^{\circ} \mathrm{C}$ and the highest $(P<0 \cdot 01)$ level was reached when adipocytes were exposed to $41^{\circ} \mathrm{C}$. Figure $4 \mathrm{~B}$ shows that Hspa2 mRNA was dramatically stimulated $(P<0 \cdot 05)$ already after 2 -h exposure to $41^{\circ} \mathrm{C}$ and peaked within 4 -h exposure. This was followed by a stable period of $4 \mathrm{~h}$ (from 4th to 8th h) and after $8 \mathrm{~h}$ declined toward the basal level until the end of the heat shock period. No time-dependent differences in $\mathrm{Hspa2}$ mRNA expression were observed at 37 and $39^{\circ} \mathrm{C}$.

Ppary mRNA was up-regulated in a temperaturedependent manner (Fig. 4C). At $41{ }^{\circ} \mathrm{C}$ Ppary mRNA began to increase early, after 2-h exposure, and peaked at $8 \mathrm{~h}$, then gradually decreased (Fig. 4D). Under 37 and $39^{\circ} \mathrm{C}$, no significant differences were observed in Ppary mRNA level among time of exposure.
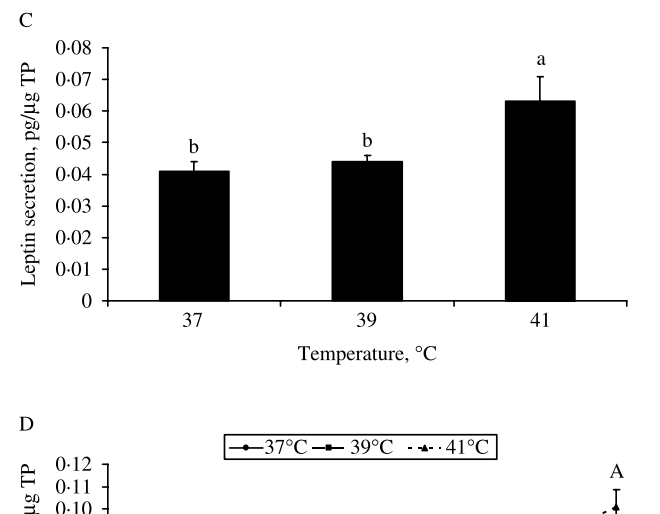

incubation
and $24 \mathrm{~h}$
$0 \cdot 6 \%$ and
ple (time 0 )
exposure
pary gene
pocytes by
and Ppary
shown in
timulated
to level was $41^{\circ} \mathrm{C}$.
ramatically
are to $41^{\circ} \mathrm{C}$
llowed by a
d after $8 \mathrm{~h}$
of the heat
s in $H s p a 2$
39 . 

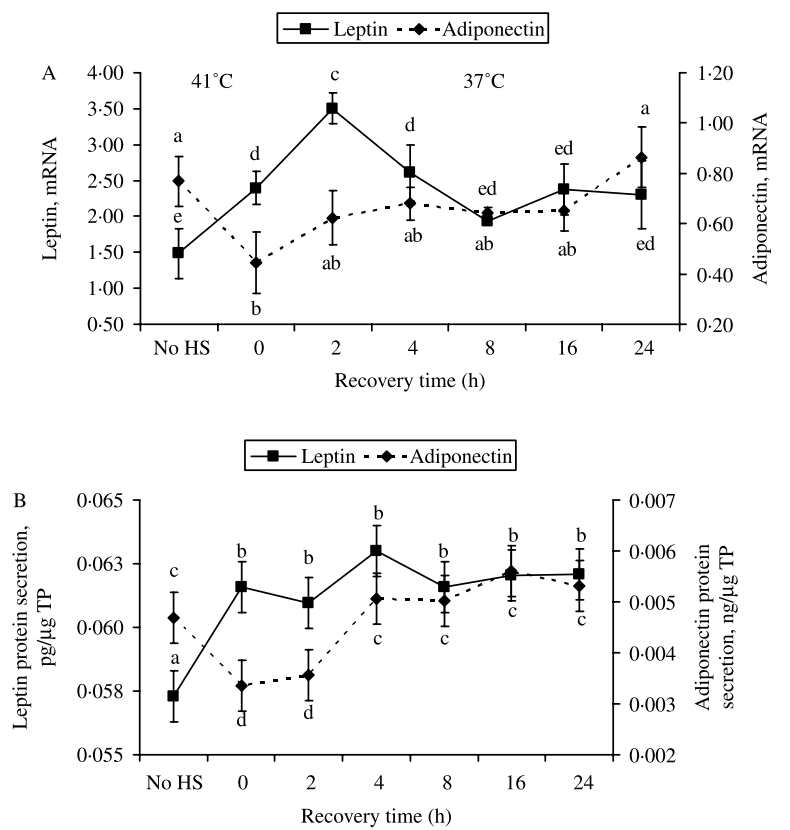

Figure 3 Kinetics of $(A)$ adiponectin and leptin mRNA and $(B)$ protein secretion. The cells were given heat shock for $2 \mathrm{~h}$ at $41^{\circ} \mathrm{C}$, then kinetics of adiponectin and leptin mRNA and protein secretion were studied after $2,8,16$, and $24 \mathrm{~h}$ exposure at $37^{\circ} \mathrm{C}$. Each mRNA level was determined using quantitative real-time PCR as described under Materials and methods. Values are normalized to mouse 18s rRNA expression. Concentrations of adipokines were determined by ELISA and adjusted for total protein (TP) levels in the cell lysate. Results are LSmeans \pm S.E.M. of triplicate determinations. No HS, no heat shock. $\left({ }^{\mathrm{a}, \mathrm{b}, \mathrm{c}, \mathrm{d}} P<0.05\right.$ between hours.)
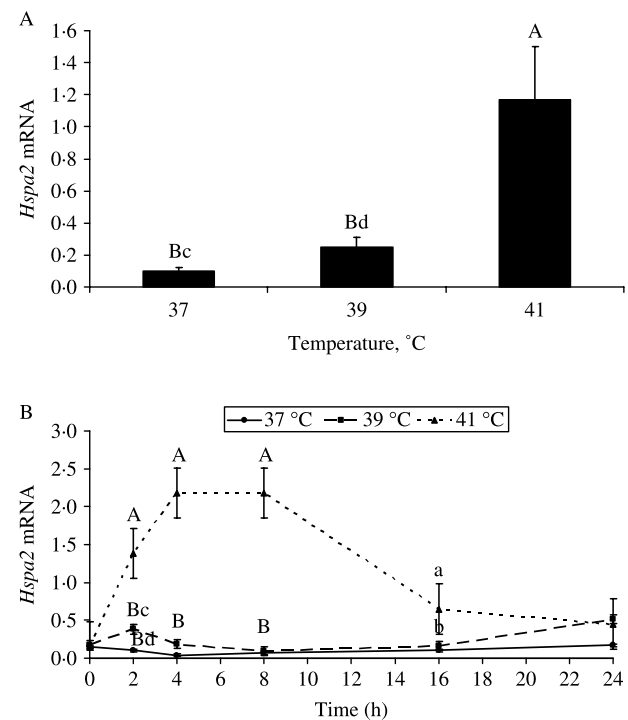

Figure 4 Temperature-dependent (A) Hspa2 and (C) Ppary mRNA, kinetic of heat shock response of (B) Hspa2 and (D) Ppary mRNA expressions in 3T3-L1 adipocytes. Each mRNA level was determined using quantitative real-time PCR as described under Materials and methods. Values are normalized to mouse 18s rRNA expression. Results are LSmeans \pm S.E.M. of triplicate determinations. $(A)$ and (C) report the overall means of time points excluding time 0 . $\left({ }^{a, b}, \mathrm{c}, \mathrm{d} P<0.05 ;{ }^{A}, \mathrm{~B} P<0.01\right.$ between temperatures or between temperatures within hours.)

\section{Cell viability in adipocytes treated with high temperatures} viability (Fig. 5A and $\mathrm{B}$ ).

\section{Discussion}
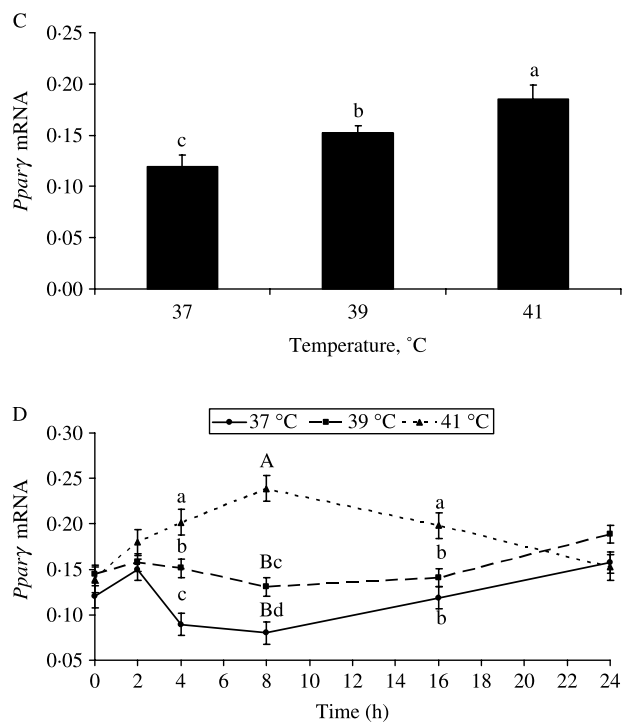

In the next set of experiments, to assess whether heat shock influenced gene expression of adipokines through a decrease in cells viability, we performed an XTT assay. This assay indicated that the exposure to different temperatures and times did not affect cell

The present study provides the first evidence on the effect of heat shock on adiponectin and leptin gene expression and secretion in 3T3-L1 adipocytes. The results demonstrate that the expression of the two adipokines is differentially regulated at the temperatures tested. Compared with control temperature $\left(37^{\circ} \mathrm{C}\right)$, adiponectin mRNA and secretion levels were increased when adipocytes were exposed to $39^{\circ} \mathrm{C}$, whereas leptin remained unchanged. When temperature increased up to $41{ }^{\circ} \mathrm{C}$, adiponectin was significantly decreased, whereas leptin was increased compared with $37^{\circ} \mathrm{C}$ (Figs $\left.1-3\right)$. The absence of a modification in cell viability between temperatures was observed. Those results testify that the temperature-related differences observed in the adipocytokines gene expression and protein secretion were probably related to a direct effect of heat shock on metabolic activity of adipocytes. 

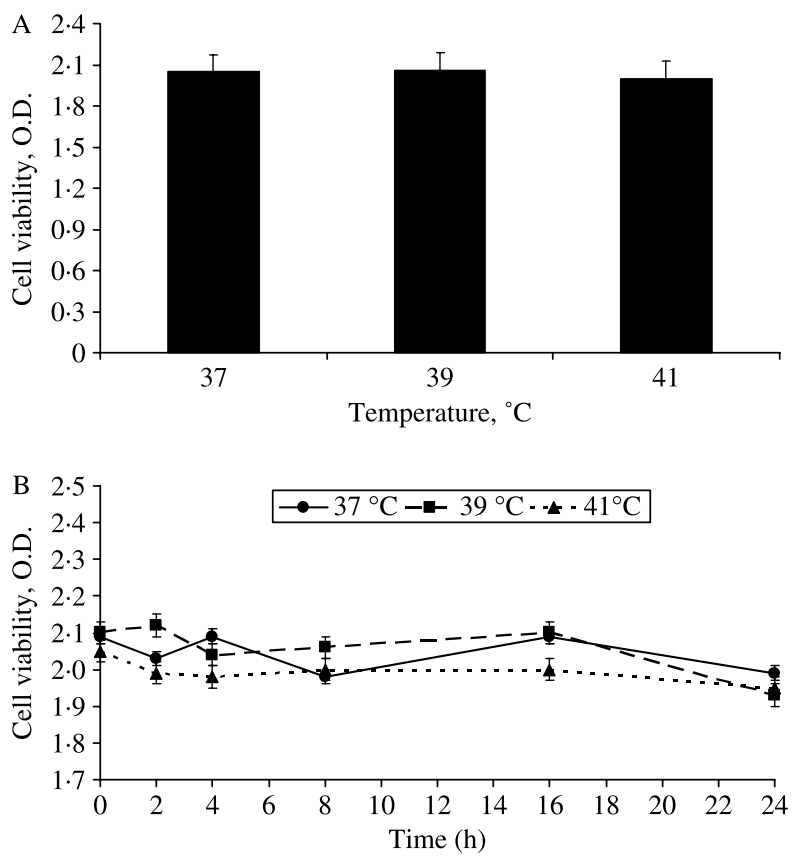

Figure 5 (A) Temperature-dependent and (B) kinetic of heat shock response of viability of 3T3-L1 adipocytes. Cells were incubated at different temperatures as mRNA analysis and then were assayed using XXT absorbance. Results are LSmeans \pm s.E.M. of triplicate determinations and expressed as optical density (OD). (A) reports the overall means of time points excluding time 0 .

Park et al. (2005) reported that the increase of $1-2{ }^{\circ} \mathrm{C}$ from physiological temperature represents a mild heat shock for the cells, whereas higher temperatures may lead to severe heat shock. Those authors also suggested that heat shock may act as one of physico-chemical signals. Changes in the fluidity of membrane lipids, induced by high temperature, may cause transduction of a signal, which would induce cell heat shock response, such as heat shock proteins expression, and activation of several important regulatory proteins (Park et al. 2005). In the present study, we investigated the gene expression of Hspa2, a well-known marker of cell injury, which has not been examined before in differently heat-shocked mouse adipocytes. Our data provide evidence that $\mathrm{Hspa} 2$ gene expression in adipocytes was increased already at $39^{\circ} \mathrm{C}$ and the highest level was reached at $41^{\circ} \mathrm{C}$. Moreover, only in cells exposed to $41^{\circ} \mathrm{C}$, was $H s p a 2$ gene expression increased in the first $4 \mathrm{~h}$ and returned to basal levels at 16-h exposure. A similar Hspalbgene expression behavior was observed by Collier et al. (2006) in bovine mammary epithelial cells exposed to $42^{\circ} \mathrm{C}$ for $24 \mathrm{~h}$. Those authors attributed to these changes the signal of the end of cell thermotolerance associated with the increased expression of genes in the apoptotic pathways. On the basis of both levels and behavior of $H s p a 2$ mRNA observed in the present study and results from Collier et al.
(2006), it is possible to indicate that $41{ }^{\circ} \mathrm{C}$ represents a severe heat shock and $39^{\circ} \mathrm{C}$ represents a mild heat shock for 3T3-L1 adipocytes. The different response of adipokines gene and protein expression to severe or mild heat shock might be due to the activation of different molecular mechanisms by adipocytes.

The mechanisms of changes in the expression of adipokines by heat shock remain unknown. However, differences in time intervals from the beginning of heat exposure to a significant changes of mRNA and protein levels of each adipokine, suggest that various mechanisms might be involved in the regulation of adipokine expression. Our results show that Ppary expression was up-regulated in a temperature-dependent manner. Anderson et al. (2004) reported a protective role of Ppara in primary hepatocytes from mice after chemical-induced stress. Those authors, using transcript profiling genes, observed an altered regulation of heat shock-inducible genes involved in tissue protection by Ppara. In particular, the activation of Ppara regulated the expression of chaperone genes involved in protein folding, and genes involved in proteasomal degradation of damaged proteins. Genes regulated by Ppara partially overlapped with genes regulated by heat and oxidative stress-inducible transcription factors. The upregulation and changes of Ppary mRNA in response to mild and severe heat shock, found in the present study, show for the first time a direct effect of heat on regulation of Ppary gene expression, and support the role in tissue protection by Ppars demonstrated by Anderson et al. (2004). Furthermore, as well known, Ppar $\gamma$ has a role in regulating adipokines expression (Panunti \& Fonseca 2006). In particular, activation of Ppar $\gamma$ dramatically represses leptin gene transcription in human and in 3T3L1-cells (Kallen \& Lazar 1996), and increases both adiponectin gene expression and circulating adiponectin levels in animals, in humans, and in in vitro studies (Havel 2002, Patel et al. 2003). Since at $41^{\circ} \mathrm{C}$ both Ppary and leptin mRNA were at their peak, and adiponectin mRNA was repressed, the changes of leptin and adiponectin mRNA levels in cells exposed to severe heat shock may not be attributable to Ppary modulation. By contrast, the upregulation of adiponectin by cells exposed to $39^{\circ} \mathrm{C}$ might be, in part, modulated by the increased Ppary mRNA.

The present report proposes some questions as to why severe heat shock differently affected the gene expression and secretion of adiponectin and leptin. We suggest that the upregulation of leptin expression in adipose cells from heat shock was probably one of the mechanisms involved in the thermoregulatory processes to limit body hyperthermia by a central action that is responsible for the decrease of feed intake, energy metabolism, and body fat (Houseknecht $e t$ al. 1998). Moreover, adipocytes express leptin receptors making it possible for leptin to act directly on 
adipocytes for regulating energy and metabolism. This 'short-loop' leptinergic system is independent of the far more complex hypothalamic 'long loop' energy regulation (Wang et al. 2005). Another possible mechanism that may explain the upregulation of leptin in severe heat-shocked cells is the role of leptin in inducing adipocyte apoptosis as recently demonstrated by Ambati et al. (2007). Our data on leptin changes in severe heat-shocked 3T3-L1 adipocytes might indicate a pro-apoptotic signal of leptin. Beside the increase of leptin expression as a consequence of a possible adaptative response to heat shock, downregulation of adiponectin might be explained as a cell heat shock response that was accompanied by a reduction in protein synthesis, favoring the induction of heat shock response over the ongoing gene program (Linquist 1986, Collier et al. 2006).

The upregulation of leptin and downregulation of adiponectin determined by severe heat shock, found in the present study, might contribute to explain the alteration of energy and lipid metabolism observed in cattle exposed to hot environment (Ronchi et al. 1999). The future climatic scenarios describing an increase in global mean temperatures and in marked changes in the frequency of temperature extremes suggest further investigations are required on changes and biological role of adipokines in farm animals exposed to heat shock conditions.

The downregulation of adiponectin and upregulation of leptin by severe heat shock found in the present study, are likely comparable with the deregulation of those adipokines observed in humans suffering from some pathological conditions such as obesity, atherosclerosis, diabetes type 2, and metabolic syndrome (Kamigaki et al. 2006, Lafontan \& Viguerie 2006). Altered adipokines levels have been observed in a variety of inflammatory conditions (Fantuzzi 2005). Adiponectin has a potent anti-inflammatory effect, whereas leptin exerts a proinflammatory role, (Fantuzzi 2005). Moreover, Moseley (1998) reported a role of Hsps in the inflammatory response, participating in cytokine signal transduction and in the control of cytokines gene expression. Therefore, changes of adipokines gene and protein expression and Hspa2 gene expression, observed in adipocytes under severe heat shock, might be responsible for a proinflammatory status possibly linked with major susceptibility to insulin resistance (Ailhaud 2006) and CVD (Fantuzzi 2005) in heat-stressed subjects. Findings of the present study encourage further studies to verify whether heat shockinduced impairment of adipokines biology may be a cofactor for aggravating the clinical status observed in patients suffering from the above-mentioned metabolic diseases and exposed to heat or heat waves.

In summary, the current study provides the first evidence about a direct effect of heat shock on adiponectin and leptin gene and protein expression, and on Ppary gene expression in 3T3-L1 adipocytes. The mechanisms through which severe heat shock modifies adipokines ratio are not clarified, but we demonstrated that Ppar $\gamma$ is not involved. Further in vivo studies are necessary to confirm the association between adipokines expression and heat shock and to elucidate the underlying mechanisms.

\section{Declaration of interest}

The authors declare that there is no conflict of interest that could be perceived as prejudicing the impartiality of the research reported.

\section{Funding}

This work was supported by funding from Italian Government Minister of University and Research (FIRB Special Project).

\section{References}

Ailhaud G 2006 Adipose tissue as a secretory organ: from adipogenesis to the metabolic syndrome. Comptes Rendus Biologies 329 570-577.

Ambati S, Kim HK, Yang JY, Lin J, Della-Fera MA \& Baile CA 2007 Effects of leptin on apoptosis and adipogenesis in 3T3-L1 adipocytes. Biochemical Pharmacology 73 378-384.

Anderson SP, Howroyd P, Liu J, Qian X, Bahnemann R, Swanson C, Kwak MK, Kensler TW \& Corton JC 2004 The transcriptional response to a peroxisome proliferator-activated receptor alpha agonist includes increased expression of proteome maintenance genes. Journal of Biological Chemistry 279 52390-52398.

Arita Y, Kihara S, Ouchi N, Takahashi M, Maeda M, Miyagawa J, Hotta K, Shimomura I, Nakamura T, Miyaoka K et al. 1999 Paradoxical decrease of an adipose specific protein, adiponectin, in obesity. Biochemical and Biophysical Research Communications 257 79-83.

Beede DK \& Collier RJ 1986 Potential nutritional strategies for intensively managed cattle during thermal stress. Journal of Animal Science 62 543-554.

Bernabucci U, Lacetera N, Ronchi B \& Tardone A 2002 Markers of oxidative status in plasma and erythrocytes of transition dairy cows during hot season. Journal of Dairy Science 85 2173-2179.

Bernabucci U, Lacetera N, Basiricò L, Ronchi B, Morera P, Seren E \& Nardone A 2006 Hot season and BCS affect leptin secretion in periparturient dairy cows. Journal of Dairy Science 89348.

Bertoni G 1998 Effect of heat stress on endocrine-metabolic and reproductive status of dairy cows. Zootecnica e Nutrizione Animale $\mathbf{2 4}$ 273-282.

Braga ALF, Zanobetti A \& Schwartz J 2002 The effect of weather on respiratory and cardiovascular deaths in 12 US cities. Environmental Health Perspectives 110 859-863.

Collier RJ, Stiening CM, Pollard BC, VanBaale MJ, Baumgard LH, Gentry PC \& Coussens PM 2006 Use of gene expression mcroarrays for evaluating environmental stress tolerance at the cellular level in cattle. Journal of Animal Science 84 E1-E13.

Fantuzzi G 2005 Adipose tissue, adipokines and inflammation. Journal of Allergy and Clinical Immunology 115 911-919.

Friedman JM 2002 The function of leptin in nutrition, weight and physiology. Nutrition Reviews 60 S1-S14.

Goldstein BJ \& Scalia R 2004 Adiponectin: a novel adipokine linking adipocytes and vascular function. Journal of Clinical Endocrinology and Metabolism 89 2563-2568. 
Hall JE, Crook ED, Jones DW, Wofford MR \& Dubbert PM 2002 Mechanisms of obesity-associated cardiovascular and renal disease. American Journal of the Medical Sciences 324 127-137.

Havel PJ 2002 Control of energy homeostasis and insulin action by adipocyte hormones: leptin, acylation stimulating protein, and adiponectin. Current Opinion in Lipidology 13 51-59.

Havel PJ 2004 Update on adipocytes hormones. Regulation of energy balance and carbohydrate/lipid metabolism. Diabetes 53 143-151.

Hotta K, Funahashi T, Arita Y, Takahashi M, Matsuda M, Okamoto Y, Iwahashi H, Kuriyama H, Ouchi N, Maeda K et al. 2000 Plasma concentrations of a novel adipose-specific protein, adiponectin, in type 2 diabetic patients. Arteriosclerosis, Thrombosis, and Vascular Biology 20 1595-1599.

Houseknecht KL, Baile CA, Matteri RL \& Spurlock ME 1998 The biology of leptin: a review. Journal of Animal Science 76 1405-1420.

Kallen CB \& Lazar MA 1996 Antidiabetic thiazolidinediones inhibit leptin (ob) gene expression in 3T3-L1 adipocytes. PNAS 93 5793-5796.

Kamigaki M, Sakaue S, Tsujino I, Ohira H, Ikeda D, Itoh N, Ishimaru S, Ohtsuka Y \& Nishimura M 2006 Oxidative stress provokes atherogenic changes in adipokine gene expression in 3T3-L1 adipocytes. Biochemical and Biophysical Research Communications 339 624-632.

Kattenberg A, Giorgi F, Grassl H, Mehl GA, Mitchell JFB, Stouffer RJ, Tokioka T, Weaver AJ \& Wigley TML 1996 Climate modelsprojections of future climate. In Climate Change 1995. The Science of Climate Change. Contribution of Working Group I to the Second Assessement Report of the Intergovernmental Panel on Climate Change, pp 285-357. Eds JT Houghton, LG Meira-Filho, BA Callander, N Harris, A Kattenberg \& K Maskell. Cambridge, UK: Cambridge University Press.

Klein J, Perwitz N, Kraus D \& Fasshauer M 2006 Adipose tissue as source and target for novel therapies. Trends in Endocrinology and Metabolism 17 26-32.

Lacetera N, Bernabucci U, Scalia D, Ronchi B, Kuzminsky G \& Nardone A 2005 Lymphocyte functions in dairy cows under hot environment. International Journal of Biometeorology 50 105-110.

Lacetera N, Bernabucci U, Scalia D, Basiricò L, Morera P \& Nardone A 2006 Heat stress elicits different responses in peripheral blood mononuclear cells from Brown Swiss and Holstein cows. Journal of Dairy Science 89 4606-4612.

Lafontan M \& Viguerie N 2006 Role of adipokines in the control of energy metabolism: focus on adiponectin. Current Opinion in Pharmacology 6 1-6.

Linquist S 1986 The heat-shock response. Annual Review of Biochemistry 55 1151-1191.

Margetic S, Gazzola C, Pegg GG \& Hill RA 2002 Leptin: a review of its peripheral actions and interactions. International Journal of Obesity 26 1407-1433.

McGeehin MA \& Mirabelli MC 2001 The potential impacts of climate variability and change on temperature-related morbidity and mortality in the United States. Environmental Health Perspectives 109 $185-190$.
Morabito M, Modesti PA, Cecchi L, Crisci A, Orlandini S, Maracchi G \& Genuini GF 2005 Relationships between weather and myocardial infarction: a biometeorological approach. International Journal of Cardiology 105 288-293.

Moseley PL 1998 Heat shock proteins and the inflammatory response. Annals of the New York Academy of Sciences 856 206-213.

Naughton MP, Henderson A, Mirabelli MC, Kaiser R, Wilhelm JR, Kieszak SM, Rubin GH \& McGeehin MA 2002 Heat-related mortality during a 1999 heat wave in Chicago. American Journal of Preventive Medicine 22 221-227.

Panunti B \& Fonseca V 2006 Effects of PPAR $\gamma$ agonists on cardiovascular function in obese, non-diabetic patients. Vascular Pharmacology 45 29-35.

Park HG, Han SI, Oh SY \& Kang HS 2005 Cellular responses to mild heat stress. Cellular and Molecular Life Sciences 62 10-23.

Patel NG, Holder JC, Smith SA, Kumar S \& Eggo MC 2003 Differential regulation of lipogenesis and leptin production by independent signalling pathways and rosiglitazone during human adipocyte differentiation. Diabetes 52 43-50.

Pittas AG, Joseph NA \& Greenberg AS 2004 Adipocytokines and insulin resistance. Journal of Clinical Endocrinology and Metabolism 89 $447-452$.

Ronchi B, Bernabucci U, Lacetera N, Verini Supplizi A \& Nardone A 1999 Distinct and common effects of heat stress and restricted feeding on metabolic status of Holstein heifers. Zootecnica $e$ Nutrizione Animale 25 11-20.

Ronchi B, Stradaioli G, Verini Supplizi A, Bernabucci U, Lacetera N, Accorsi PA, Nardone A \& Seren E 2001 Influence of heat stress and feed restriction on plasma progesterone, estradiol-17 $\beta$, LH, FSH, prolactin and cortisol in Holstein heifers. Livestock Production Science 68 231-241.

Rothenbacher D, Brenner H, Marz W \& Koenig W 2005 Adiponectin, risk of coronary heart disease and correlations with cardiovascular risk markers. European Heart Journal 26 1640-1646.

SAS 1999. SAS User's Guide: Statistics Version 8, Cary, NC, USA: SAS Institute Inc.

Semenza JC, McCullough JE, Flanders WD, McGeehin MA \& Lumpkin JR 1999 Excess hospital admissions during the July 1995 heat wave in Chicago. American Journal of Preventive Medicine 16 269-277.

Trayhurn P 2005 Endocrine and signalling role of adipose tissue: new perspectives on fat. Acta Physiologica Scandinavica 184 285-293.

Valentini A 2006 www.unitus.it/sag.

Wang M, Orci L, Ravazzola M \& Unger RH 2005 Fat storage in adipocytes requires inactivation of leptin's paracrine activity: implication for treatment of human obesity. PNAS 102 18011-18016.

Received in final form 9 October 2008

Accepted 6 November 2008

Made available online as an Accepted Preprint 7 November 2008 